\title{
Nuclear Technopolitics in the Soviet Union and Beyond - An Introduction
}

Nuclear energy epitomises the ambiguity of high modernity like no other technology. In the history of the Soviet Union, it played an exceptionally prominent role, initially accelerating its ascent to superpower status and bolstering its visions of the future, but eventually hastening its demise in the wake of the Chernobyl disaster in 1986.

There can be little doubt that without nuclear weapons, the Soviet Union would not have been able to consolidate its hard-won victory in World War II and to achieve superpower status. In a massive effort that combined domestic research in nuclear physics with the knowledge of captive German scientists and intelligence about the American Manhattan project and drew on the resources of the country's military-industrial complex and the Gulag system, the Soviet Union developed its own atomic bomb in record time and tested its first nuclear device in 1949. By 1953, it was also in possession of the hydrogen bomb and had thus achieved technological parity with the United States. ${ }^{1}$ In fact, with the successful test of the world's first intercontinental ballistic missile in 1957, the Soviet Union had taken the lead in developing a powerful launch vehicle to deliver thermonuclear warheads across the globe.

No less important - in ideological terms even more so than in economic ones - was the Soviet Union's civilian nuclear programme. Soviet atomic scientists advocated harnessing the atom's power for electricity generation as early as the late $1940{ }^{2}{ }^{2}$ and the CPSU was quick to realise the economic and propagandistic potential of nuclear power. ${ }^{3}$ Only one year after the detonation of their first $\mathrm{H}$-bomb, and in response to Dwight $\mathrm{D}$. Eisenhower's Atoms for Peace speech, Soviet nuclear scientists connected the world's first nuclear power plant to the grid in Obninsk near Moscow. While the quantity of energy produced was negligible, the amount of publicity it generated for the Soviet state was enormous. ${ }^{4}$ Soviet propaganda could now juxtapose the belligerent capitalist atom of Hiroshima and Nagasaki with its seemingly peaceful socialist twin, eager to serve the

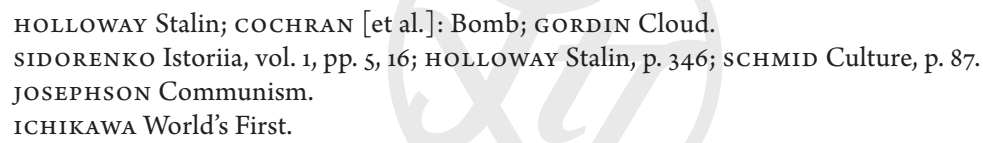


cause of human progress. ${ }^{5}$ Following up on the initial success with a series of important technological innovations and the eventual mass deployment of power reactors, the Soviet Union managed to further underscore its technological prowess in this field. From the 1960 s to the 1980 s, atomic energy lent much-needed credibility to the concept of the Scientific-Technological Revolution (STR) - the promise that technoscientific progress would accelerate socio-economic development and quickly create universal wealth. ${ }^{6}$

In international perspective, the nuclear power programme added greatly to the Soviet Union's appeal as a partner in technoscientific matters. ${ }^{7}$ In the 1960s and 1970s, Western countries such as the United States and France thought it in their best interest to closely cooperate with the USSR in the field of civilian nuclear research and development, and right until the end of the USSR - undeterred even by the Chernobyl accident - most socialist countries in Central Europe were eager to partner with the Soviet Union to increase their share of nuclear power generation. ${ }^{8}$ Atomic energy, alongside space-flight, was thus one of the few fields where the Soviet Union could plausibly claim to be at the helm of human progress.

In the long run, however, Soviet nuclear modernity came at a cost that was prohibitively high in more than just monetary terms. Keeping pace with the United States in the nuclear arms race required enormous investments which put significant strain on the Soviet state budget, while nuclear power stations fell decidedly short of the promise to provide "energy too cheap to meter". 9 An even more important aspect was the social and ecological cost of the Soviet nuclear programme - from the massive exploitation of forced labour in its early phase (and, to some extent, also in its later ones) to the ecologi$\mathrm{cal}$ and health calamities associated with the release of radioactivity in the wake of bomb tests, accidents and negligent waste disposal. In 1986, the Chernobyl catastrophe - the largest civilian nuclear accident to date - ushered in the final demise of "atomic-powered Communism". ${ }^{\circ}$ Five years later, Soviet Communism ceased to exist - but surprisingly, a quarter of a century later, visions of nuclear futures once again abound in Russia and other countries of the post-Soviet and post-socialist space, such as Kazakhstan, Belarus and Hungary - a development that will also be reflected upon in this volume.

5 As a Soviet author claimed in 1968, Soviet man 'rehabilitated' the atom after Hiroshima and Nagasaki. GUBAREv Goroda, p. 18. On Hiroshima as a central topos in Soviet nuclear-related discourse, see RENNER Ort.

6 HOFFMANN/LAIRD STR and Soviet foreign policy; GUTH Future. For samples of the contemporary Soviet literature on the STR, see e.g. Man, Science, Technology; volkov Man; FED oseyev Significance. The concept was originally inspired by the British Marxist philosopher J. D. Bernal. See TEICH Bernal.

7 See Stefan Guth's contribution to this volume.

8 For cooperation across the bloc divide, see the contributions by Stefan Guth and Fabian Lüscher to this volume. For collaboration within the CMEA, see schmid Colonization.

9 This notorious expression was coined by Lewis Strauss, the chairman of the U. S. Atomic Energy Commission, in 1954, but the alleged "cheapness" of nuclear energy was just as important to Soviet proponents of nuclear energy. See SCHMID Producing Power, pp. 22, 28, 36-37. 


\section{Bridging the Gap between Stalin's Bomb and Chernobyl: a Long-Term View}

In view of these momentous developments, Soviet nuclear history has attracted keen interest from researchers ever since the collapse of the USSR. Unsurprisingly, its tumultuous first and last phases have garnered the lion's share of scholarly attention. Thus, the era of "Stalin and the bomb" was not only the subject of David Holloway's pioneering study under that very title and a number of later books, ${ }^{11}$ but also of a comprehensive Russian edition of archival materials. ${ }^{12}$ Its final phase - the era of Chernobyl and Gorbachev - has also prompted numerous studies. ${ }^{13}$

By contrast, after two and a half decades of research, the interim period (1953-1986) has yet to receive comparable attention. More often than not, it is treated as a mere epilogue to the bomb project or as a preface to the Chernobyl catastrophe. ${ }^{14}$ This glaring omission has motivated the first purpose of this volume: to provide a long-term perspective on Soviet nuclear history with an emphasis on the Khrushchev and Brezhnev periods. This three-decade long interim phase of Soviet atomic history deserves to be studied in its own right. Despite obvious continuities, it differed markedly from the period of Stalin and the Bomb; and while it undoubtedly created institutional, economic and technological preconditions for the Chernobyl catastrophe, its storyline still cannot be reduced to the declensionist narrative of the third phase without loosing sight of many important developments.

To outline just a few of these processes, the mid-1950s to 1970s saw the transformation of what had hitherto been an atomic project still very much rooted in the all-out mobilisational culture of the wartime effort into a regular industry comprised of a sprawling archipelago of nuclear cities, production facilities and test sites. As improvisation gave way to expert culture, ${ }^{15}$ the Soviet nuclear sector became highly institutionalised. ${ }^{16}$ Between the mid-1950s and the mid-1970s, Soviet nuclear research and development proceeded at a quick pace, producing impressive technological innovation (such as breeder reactors) and cutting-edge scientific advancements in fields such as nuclear fu-

holloway Stalin; Gordin Cloud; cochran [et al.]: Bomb. Kate Brown's recent study also focuses mainly on the early phase of the Soviet (and American) military atomic project. BROWN Plutopia.

12 RIABEv (ed.): Proekt.

13 To cite the most recent: schmid Power; Geist Fallout; ARndt (ed.): Politik; DALhouski Tschernobyl; KUChInskaya Politics; Gestwa Katastrojka.

14 Sonja Schmid's recent study is to date the only analysis to treat the history of the Chernobyl nuclear power plant (and RBMK reactors in general) in its own right rather than merely as a prehistory to the 1986 accident. SCHMID Power.

15 On expert culture, see KoHLRAUSCH/TRISCHLER Building Europe on Expertise; KOHLRAUSCH/STEFFEN/WIEDERKEHR (eds.): Expert Cultures; WUNDERLE Experten.

16 Research on the institutional development of the Soviet nuclear sector is still scarce, although SCHMID Power, pp. 41-65, and VASILIEva Soleils, pp. 163-192, offer first insights. Post-Soviet insiders' accounts such as the compendium by PETROS'IANTS [et al.] (eds.): Industriia, provide further valuable information. Additionally, a wealth of chronicles and memoirs about individual nuclear research, planning and production facilities is available at http://elib.biblioatom.ru (27.10.2017). 
sion and the study of transuranic elements. ${ }^{17}$ The same period also witnessed the Soviet Union's integration in international, multilateral and bilateral networks of technological exchange as well as in the new field of nuclear diplomacy. The USSR successfully positioned itself as a major player within the framework of the UN-sponsored Geneva Conferences and the newly founded International Atomic Energy Agency (IAEA), ${ }^{18}$ promoted and coordinated nuclear research and development throughout the socialist countries (and, to some extent, the Third World), ${ }^{19}$ and entered substantial cooperation agreements with capitalist countries, in particular with France and the United States. ${ }^{20}$ Between the late 1960 s and early 1980s, the USSR embarked on a large-scale deployment of nuclear power plants, a programme epitomised by the Atommash factory, whose giant assembly lines were to churn out standardised reactors at low costs, although this vision never fully materialised. ${ }^{21}$ Feasibility fantasies were up-scaled even faster: in the 1970 and 1980s, Soviet technologists envisioned the construction of large-scale nuclearpowered desalination plants along the arid Southern flank of the Union from Ukraine to Vladivostok, and, as a next step, peaceful nuclear explosions and nuclear-powered pumping stations were to make possible the diversion of Siberian rivers to the South of the Soviet Union. ${ }^{22}$ However, these utopias were juxtaposed by the nightmares of nuclear accidents long before Chernobyl, the largest of them being the explosion of a storage facility of liquid radioactive waste at the Maiak processing plant in $1957 .{ }^{23}$ Accidents such as this one, combined with the more gradual effects of radioactive pollution of the environment and dose accumulation in human bodies, afforded the Soviet atomshchiki ample experience of the ecological and health calamities associated with nuclear modernity. Influenced by insights into the devastating consequences of nuclear war and proliferation, many nuclear scientists and engineers gradually adopted a more nuanced and ambiguous stance towards the opportunities and risks associated with nuclear technologies. Apart from a few spectacular cases - the most prominent being Andrei Sakharov and Zhores Medvedev - the resulting discussions remained concealed from the public behind a façade of official confidence and secrecy, but differences of opinion on questions such as military versus civilian priorities or technological audacity versus

17 For an overview of technological developments, see Josephson Atom. For a more detailed account of the civilian nuclear programme, see SID ORENKo Istoriia.

18 On Soviet participation in international conferences and organisations such as the IAEA, see Fabian Lüscher's contribution to this volume; Holloway Creation.

19 For Soviet nuclear cooperation with Central European socialist countries, see SCHMID Colonization. The nuclear research centre at Dubna (JINR), which developed into a "Soviet CERN", has yet to be studied in depth. It is the subject of Roman Khandozhko's ongoing research. Starting in 1959, the CERN and the JINR collaborated in several projects and organised mutual visits by research teams. LOCK History of the Collaboration.

20 On trans-systemic cooperation, Stefan guth in this volume, and also petros'iants [et al.] (eds.): Industriia, pp. 991-1024.

21 On deployment, see Sonja Schmid's contribution to this volume. On Atommash, see Josephson Atom, pp. $81-108$.

22 Weiner Corner, p. 422 f.; Josephson Atom, p. 248; white Water.

23 See Laura Sembritzki's contribution to the present volume. The first account of the Maiak accident was MEDVEDEV Nuclear Disaster. 
safety were substantial and can now be partly unearthed in archival records and memoirs. The contributions to the present volume provide new insights into many of these aspects, thus adding considerably to our knowledge of this protracted interim period of Soviet nuclear history. At the same time, most contributions view this in-between period in a larger, long-term perspective beyond conventional chronological divides of Soviet political history.

\section{Technopolitics - An Interdependent Perspective}

Considering its significant implications for many domains of human existence, nuclear technoscience has been studied from a broad range of angles over the last few decades - including political and geopolitical, economic and social, cultural and ecological perspectives. At the same time, it has prompted heated debates between technological determinists and social constructivists: were the ambiguities of nuclear civilisation an inevitable consequence of the unstoppable juggernaut of technoscientific progress or should they rather be seen as the outcome of specific agendas promoted by powerful interest groups and coalition builders? Recent approaches strive for a middle ground by acknowledging both the ways in which social and cultural factors predicate technological choices and the potential of technological artefacts, institutions and networks to channel further socio-economic and political developments. ${ }^{24}$ These STS discussions have added further depth to the historical study of science and technology and its broader implications.

In response to the collapse of the USSR and the end of the Cold War arms race, historiography first approached Soviet nuclear history from a (geo)political perspective. ${ }^{25}$ Josephson's Red Atom offered an early technological outline of the Soviet civilian nuclear programme, focussing on overarching visions and decision-making processes. Josephson also explored the cultural dimension of what he aptly described as "atomicpowered Communism" - a line of inquiry which has since been pursued further in a number of articles by Sonja Schmid and others. ${ }^{26}$ More recently, ecological and human health aspects, particularly those of the Chernobyl catastrophe and, to some extent, the Maiak processing plant and the Semipalatinsk test site, have been studied in depth. ${ }^{27}$ Other scholars have investigated the effects of these calamities on the formation of civil society in the Gorbachev era and the post-Soviet period..$^{28}$ Interest in the social history of the Soviet nuclear programme has hitherto mostly crystallised around its early

24 Among these approaches, actor-network theory (Bruno Latour and Michel Callon) and co-production theory (Sheila Jasanoff) have been the most prominent. See, e.g. JASANoff Idiom; LATOuR Reassembling; CALLON Acting.

25 holloway Stalin.

26 Josephson Atom; Josephson Communism; Schmid Celebrating; vizgin Fenomen; van Lente (ed.): Age.

27 petryna Life; Kuchinskaya Politics; Stawkowski Radioactive Mutant.

28 ARndt (ed.): Politik; DAlhouski Tschernobyl; Dawson Eco-Nationalism. 
phase, ${ }^{29}$ but has recently also turned to the social microcosms of late Soviet and postSoviet atomogrady. ${ }^{30}$

While Soviet nuclear history has thus clearly become a multifarious object of study, the interrelations between its various aspects have remained somewhat understudied to date. Drawing on recent work by scholars from outside the field of Soviet history who rely on hybridity, actor-network and co-production theories, the present volume explores possibilities for bringing these aspects closer together. One of the inspirations for such an attempt is Gabrielle Hecht's study of the French nuclear power programme, in which she sets out to "trace the social, political, and cultural life of reactors" - artefacts which, she argues, are best understood as "hybrids of technology and politics". ${ }^{31}$ Technopolitics can thus be defined as "the strategic practice of designing or using technology to constitute, embody, and enact political goals."32 Hecht's approach is beneficial in that it transcends old dichotomies between allegedly ideological politics and seemingly objective technoscience, thus offering a framework which allows us to more fully evaluate to what extent technologists shared the CPSU's teleological idea of progress ${ }^{33}$ and, vice versa, to what degree late Soviet visions of the future depended on technoscientific development. ${ }^{34}$ This can help us to better appreciate the work of our protagonists, who often moved with dexterity between technoscientific and political-ideological contexts.

Sara Pritchard's envirotech approach represents another useful application of the co-production paradigm. It offers a comprehensive understanding of the "dynamic imbrication" of natural and technological systems which has proven so fatefully important for nuclear history. ${ }^{35}$ Central to Pritchard's approach is the argument that nature and technology must not be seen as opposite and tightly delineated spheres, but rather as a single enviro-technical system ${ }^{36}$ composed of ecologies, artefacts, people, practices and institutions. ${ }^{37}$ Technopolitical accidents, she argues, often result from reductionist understandings of this highly dynamic and complex interaction..$^{38}$

Yet another approach with valuable implications for Soviet nuclear history is Sheila Jasanoff's concept of sociotechnical imaginaries, which she defines as "collectively held $[\ldots]$ visions of desirable futures $[\ldots]$ attainable through, or supportive of, advances in

BRown Plutopia; melnikova Artisans.

Atomogrady ("nuclear cities") refers to the new towns built for the employees of nuclear power plants and their families. STORM Scars, pp. 75-100; ŠLiAVAité Social Memory; BALOČKAItĖ Visaginas; WENDLAND Geschichte; emeliantseva Privilege.

HECHT Radiance, p. 5 .

HECHT Radiance, p. 15.

Lipovetsky Poetics.

Surprisingly, while the Soviet system was described as "technocratic socialism" decades ago, the approach of technopolitics is yet to gain broader appeal in Soviet studies. On "technocratic socialism", see HofFMANN/LAIRD Technocratic Socialism. A fairly recent article on Cold War technopolitics is based on out-dated literature on the Soviet side of the story. HECHT/EDWARDS Technopolitics.

PRITCHARD Disaster, p. 223.

PRITCHARD Disaster, p. 223.

PRITCHARD Confluence, p. 19.

PRITCHARD Disaster. 
science and technology".39 She draws attention to the public dimension of technology by emphasising that "ideas about scientific and technological futures need to gain assent outside [the] bounded communities [of scientists and technologists] in order to become full-fledged imaginaries. Often, they must latch onto tangible things that circulate and generate economic or social value [...]. This hybridisation, or co-production of ideas, materiality, and sociality happens through processes that we call embedding." ${ }^{\circ 0} \mathrm{Im}$ portantly, Jasanoff reminds us that investing imaginaries with concrete materiality can serve both to legitimise and to delegitimise sociotechnical orders and the technopolitics which produce them - a point which can only gain further analytical acuity from an analysis of the Soviet and post-Soviet case with its consecutive phases of legitimisation, delegitimisation and relegitimisation following on each other's heels.

Taken together, these approaches have, in recent years, drawn attention to the intricate web of interdependences which link the history of technoscience to almost every other field of history, thereby not only rendering the history of technoscience more multi-faceted, but also highlighting its pivotal significance for the history of high modernity as a whole.

\section{Encompassing the Local and the Global: a Multi-Level Analysis}

The insight that manipulating matter at an atomic level holds the potential to change the course of human history at a global scale has been a cause of fascination and concern ever since the dawn of the nuclear age..$^{41}$ Accordingly, the history of nuclear power has been told at various orders of magnitude, from the level of secluded laboratories to that of industrial production facilities, national nuclear programmes and superpower politics. Traditionally, for lack of access to source materials or reasons of methodological preferences, analysts of nuclear history have often followed a top-down approach which began with a bird's eye view and then attempted to fill in details where possible - an approach which was certainly justified by the sheer scope of the field of research, but is inevitably prone to the omission of important evidence.

Recently, inspired by developments in the history of science and STS scholarship, an increasing number of historians, including the contributors to this volume, have taken a different approach. They begin with a close reading of specific milieus - be they nuclear research facilities, ${ }^{42}$ atomic cities or international forums of nuclear scientists - in order to then broaden the scope of their analysis and study the larger national and international preconditions and effects of their specific object of study. As a result of this approach,

39 JASANOFF Future Imperfect, p. 4.

40 JASANOFF Worlds, p. 326. For the sociotechnical imaginaries concerning nuclear energy, see JASANOFF/ KIM Containing. For the Soviet case, see SCHмid Shaping; vizGin Fenomen.

41 Motion pictures such as the American A is for Atom (1952) or the Soviet Nash Atomnyi vek [Our Nuclear Age] (1976) provide illustrative examples of this fascination.

42 Laboratory studies offer an elaborate methodological toolkit for this kind of investigation. For an overview of the field, see LIBURKINA/NIEWÖHNER Einführung; DOING Laboratory. 
the present volume is conceptualised as a multi-level analysis of Soviet technopolitics in its local, all-Union and international dimensions. All five contributions link the local micro-logic of "doing technology" in nuclear research and production centres with the macro-logic of Soviet and global Cold War politics. Anchoring each contribution in a specific milieu uncovers largely unknown protagonists, their outlook and their particular scope of action and reveals highly situational local dynamics that are not easily visible at superordinate levels. In many cases, this approach constitutes the only way to track the actions of higher-level bodies, whose records are usually still classified for the most part. In a second step, every contribution to this volume situates the findings in an all-Union context. The government level has traditionally been the preferred frame of reference for nuclear histories, ${ }^{43}$ but only recent studies have fully exposed the intricate complexity of competing actors, shifting agendas and conflicting priorities at play here. ${ }^{44}$

Concerning the transnational and international level, recent studies have emphasised the importance of trans-systemic comparisons across the blocs and identified the study of transnational and international entanglements as a greatly rewarding subject. ${ }^{45}$ Kate Brown's comparative study of Richmond and Ozersk has highlighted striking parallels between the American plutonium production town and its Soviet counterpart. ${ }^{46}$ Gabrielle Hecht has also shifted from national to transnational nuclear histories in her recent works. In Being Nuclear, she has painstakingly traced the global-scale ramifications of uranium trade out of Africa. ${ }^{47}$ However, surprisingly little research has been conducted in the field of contacts and cooperation across the bloc divide. ${ }^{48}$ Even the scholarly examination of the IAEA's history is still in its early stages. ${ }^{49}$ With a strong focus on trans-systemic actors and their respective networks, the contributions to this volume attempt to fill in this lacuna and offer numerous insights into the global entanglement of Soviet nuclear technoscience. They trace Soviet nuclear scientists' encounters with peers from the United States and other Western countries, shed light on how Soviet radiobiology influenced and was influenced by international research in the field and track the technological collaboration between Soviet, French and U.S. nuclear engineers in fast breeder development..$^{\circ}$ By embedding Soviet nuclear history more comprehensive-

43 For an overview of national nuclear histories, see каLмвасн Revisiting, pp. 52-57.

44 неснт Radiance; SCHMid Power.

45 TURChetti [et al.]: Introduction; Gestwa/Rohdewald Verflechtungsstudien. For an overview of transnational and international approaches to nuclear history, see кALмвАCH Revisiting, pp. 58-61. The term "transsystemic" has been introduced by PÉTERI Nylon Curtain. See also DAVID-FOx Iron Curtain.

46 BROWN Plutopia.

47 неснт Nuclear. She has also edited Entangled Geographies, which includes a contribution by Sonja Schmid on CMEA cooperation in the field of nuclear energy. SCHMID Colonization.

48 One of the few exceptions to the rule is Eliza Gheorghe's work on Romania's cooperation with the United States. GHeORGhe Building Détente. Matthew Evangelista does adopt a transnational perspective, but focuses on political initiatives to limit nuclear testing rather than on techno-scientific contacts in the field of nuclear energy; EVANGELISTA Forces.

49 Elisabeth Röhrlich's IAEA history project in Vienna is currently investigating the history of this important organisation; ROEHRLICH Cold War; see also HOLLOWAY Creation.

50 See the contributions by Lüscher, Sembritzki and Guth in this volume. 
ly into a transnational perspective of entangled history, the research presented in this volume contributes to envisioning the Soviet Union in the emerging historical picture of global technopolitics. In doing so, it also helps to delineate the place of Eastern Europe more clearly in the global history of high modernity.

\section{Overview of the Contributions}

This special issue is the first output of an international research cluster on nuclear technopolitics in the Soviet Union. ${ }^{51}$ The idea for this cluster, and also for the present volume, was developed during a workshop at the University of Bern in the summer of 2015 which discussed links and mutual benefits between several existing research projects in the field..$^{2}$ Some of these links were outlined above and are considered - to varying degrees - in the following articles, all of which deal with the exploitation of atomic energy in the Soviet Union, from different perspectives but with similar key questions.

Taking the Geneva Conference on the Peaceful Uses of Atomic Energy in 1955 as a point of departure, FABIAN LÜSCHER's study focuses on the internationalisation of nuclear knowledge by analysing post-Stalinist Soviet nuclear history in conjunction with the early history of the IAEA. The Soviet Academy of Sciences played a key role in re-establishing ties with the international scientific community and serves as a vivid example allowing general reflections on the Soviet re-emergence in international discussions on nuclear energy. Although it soon handed over parts of its responsibilities for nuclear science diplomacy and international cooperation to newly founded branches of the Atomic Ministry (Sredmash), the Academy remained an important policy advisory body, maintaining close ties with research institutes and their staff as well as with the Party and state elites. With its focus on the late 1950 s and early 1960 s, the article reflects important transformations in Soviet nuclear history in the context of de-Stalinisation. It covers a period marked by a limited liberalisation of trans-systemic knowledge circulation in the field of nuclear science and highlights the interdependence of developments in top-level nuclear science, domestic and foreign science policy-making and diplomacy in the framework of international organisations, thereby analysing nuclear internationalism as a multi-faceted Cold War phenomenon which was staged in various arenas, from the Palais des Nations in Geneva to the Kremlin in Moscow.

In 1957, two years after the first Geneva Conference, a major accident in a Soviet military nuclear facility in Maiak in the Southern Urals region caused the contamination of vast areas around the Kyshtym river. While the Soviet press was always quick to point out the radiation hazards associated with British and American arms testing, the Kyshtym disaster remained shrouded in secrecy for decades. Still, the catastrophe trig-

51 For an overview of the project and its activities, see https://nuctechpol.org (29.10.2017).

52 For a summary of the conference papers, see report of the conference Zwischen Utopie und Apokalypse. Nukleare technopolitics in der Sowjetunion, University of Bern, September 23, 2015, in: H-Soz-Kult, 04.09.2015, http://www.hsozkult.de/conferencereport/id/tagungsberichte-6142 (19.12.2017). 
gered the production of radiation-related knowledge, as LAURA SEMBRITZKI demonstrates in her case study. Her analysis describes how the emerging scientific discourse on radiation hazards influenced political decisions on radiation protection measures. While the author points out that international knowledge exchange in these fields was tightly restricted due to secrecy considerations, local research in the Kyshtym region nevertheless provided knowledge for radiation-related research on the all-Union level which later started to circulate internationally in more generalised forms. Although focussing on the Maiak incident and its aftermath in the 196os, the article also provides a survey of the Perestroika period, thus highlighting lines of continuity between the radiation discourses surrounding the two largest Soviet nuclear catastrophes, Maiak and Chernobyl.

STEFAN GUTH studies the ambivalence of Soviet nuclear history through the lens of a multi-purpose atomic city on the Caspian Sea. Shevchenko/Aqtau started life in the 1950 as a uranium mining camp but was later transformed into a showcase of atomicpowered Communism relying on novel reactor technology and nuclear-powered water desalination. A close reading of this chronotope of Soviet nuclear modernity makes visible the persistent parallelism of civilian and military priorities and highlights the puzzling synchrony of a model urban microcosm of Soviet STR civilisation and a forced labour complex created after the official dissolution of the Gulag. The analysis juxtaposes the project of Promethean nature improvement with its problematic ecological consequences and demonstrates how the city's sealed-off nuclear complex nevertheless became a hotspot of cooperation across the bloc divide. In a long-term perspective, the history of Shevchenko/Aqtau thus reveals the multiple and often conflicting priorities of Soviet nuclear technopolitics, tracing how they shifted over time and how they created enduring socio-economic and enviro-technical configurations which continue to shape technopolitics in present-day Russia and Kazakhstan.

Yet another facet of Soviet nuclear cities is taken up by ROMAN KHANDOzHKo. Based on biographical interviews, he analyses emerging dissident networks in the nuclear research city of Obninsk and traces the complex ties which linked the local representatives of the liberal intelligentsia to their peers in other science cities. The article discusses how the opening of a formerly 'closed city' in the wake of a partial demilitarisation of nuclear science affected its social and political dynamics and facilitated the emergence of a Soviet dissident movement. In so doing, the contribution couples local processes with overarching developments in Soviet history and shows how they radiated far beyond Moscow's sphere of influence. Beginning with a local case study, the article leads to questions of all-Union and international significance and highlights the long-term consequences of political dissent which came into effect in the nuclear scientists' political activities during Perestroika.

SONJA SCHMID's contribution presents another long-term perspective on Soviet and post-Soviet nuclear history, discussing the ways in which promoters of nuclear energy succeeded in obtaining the necessary political support for the development of a vast power industry. With its emphasis on lobbying, this contribution focuses on the intersection of economic, scientific-technological and political considerations regarding 
energy development and demonstrates how resource allocation was a decisive factor for Soviet nuclear history. By analysing arguments for and against the deployment of nuclear power over the course of several decades, the study shows how criteria for evaluating nuclear energy's potential shifted over time. It highlights the continuities and ruptures which characterised the promotion of nuclear energy in a long-term perspective. An especially instructive aspect is the inclusion of post-Soviet nuclear policy which allows the author to show how recent developments are deeply rooted in the history of the Soviet atomic project.

\section{Outlook}

The contributions to the present volume invite scholars to view not only Soviet nuclear history, but also Soviet history in general from new angles. To begin with, a long-term perspective on Soviet (and post-Soviet) nuclear history helps us understand the history of nuclear power not only in accumulative and linear terms, but also stresses the impact political and societal changes have on scientific-technological developments. Conversely, it also invites us to re-evaluate the conventional periodisation of Soviet political history, which still relies heavily on the tenures of Party leaders and a limited number of alleged watershed events. Recent research has increasingly drawn attention to the shortcomings of such an approach, ${ }^{53}$ and the Soviet nuclear project offers a telling case in point illustrating why such scepticism is warranted. Tracking the Soviet nuclear project across the 1953 divide highlights the extent to which the technocratic state, commonly associated with the Khrushchev and Brezhnev periods, was already taking shape under postwar Stalinism. Much of the infrastructural and organisational groundwork for both the military and the civilian nuclear programmes was laid in the late 1940s and early 1950s, and the scientists, engineers and administrators who became key figures in the Soviet Union's civilian nuclear programme all went through the offices and laboratories dedicated to Stalin's bomb before they started inventing, constructing and managing power reactors and particle accelerators. But at the same time, it should not be ignored that Stalin's death did herald significant paradigm changes for Soviet nuclear development, ranging from the re-establishment of international techno-scientific contacts to a notable expansion of the civilian nuclear programme. "Stagnation" is another label of periodisation for which nuclear history can offer useful qualifications. The fact that the deployment of the Soviet nuclear power programme gained its greatest momentum in the 1970 and 8 os certainly defies the cliché of standstill conventionally associated with the period. On the other hand, the fact that Soviet experts perceived the Soviet nuclear programme as falling behind the curve internationally from the mid-1970s onward shows that there was indeed a contemporary perception of deceleration. For

53 On the problems of rigid periodisation, see e.g. PLAGgenborg Sowjetische Geschichte. For studies which transcend traditional chronological boundaries, see FÜRST/JONES/MORRISSEY (eds.): Relaunch; GeSTWA Großbauten. 
the Perestroika and post-Soviet periods, nuclear history raises particularly puzzling questions with regard to how political and technological developments set each other's pace. Ironically, while Gorbachev's initial programme of scientific-technological acceleration assigned key significance to nuclear power, it was the catastrophic failure of that very technology which then hastened the shift to Glasnost' as the new mainstay of his transformative agenda. Still more paradoxically, while nuclear power and the disaster at Chernobyl played a central role in delegitimising the late Soviet system, governments in the post-Soviet space (particularly in Russia) have meanwhile fallen back on nuclear technologies in a renewed attempt to bolster their legitimacy as technocratic modernising regimes. ${ }^{54}$

Second, an interdependent perspective can draw attention to the complex ways in which techno-scientific, socio-economic, political and cultural aspects interrelate to reinforce or hamper each other's development. A number of questions raised in this volume merit further consideration. For instance, what does the Soviet case tell us about the compatibility of techno-scientific and political-ideological visions of progress, ${ }^{55}$ particularly if compared to other countries such as France? Does the Soviet and post-Soviet case testify to a particular affinity between big science on the one hand and autocratic governance on the other ${ }^{56}$ How do the vastly incommensurable timescales of nuclear technologies and nuclear ecologies affect the perception and evaluation of atomic energy over time? What can we learn about the power of (very sizable) artefacts and (very long-lived) materialities to 'store' past agency in ways which then channel future technopolitical action? Under what circumstances is nuclear energy perceived as an impenetrable Arcanum whose administration is best left to the representatives of nuclear priesthood ${ }^{57}$ or, conversely, as an all-pervasive technology whose potential to affect everybody necessarily makes it a matter of concern for grassroots democracy?

Another benefit of a multifarious approach is that it brings to the fore aspects which are easily overlooked when the focus of research is more narrowly circumscribed. For instance, Cold War historiography has long since acknowledged the "centrality of the nuclear", ${ }^{8}$ but has focused almost exclusively on the military-strategic implications of the nuclear age while largely treating the techno-scientific complex itself as a black box. ${ }^{59}$ But as it turns out, studying trans-systemic contacts on the techno-scientific level offers important insights for our understanding of Cold War superpower relations. To give another example, research on the Soviet nuclear project provides a focus on the USSR's techno-scientific elites, which have been mostly absent in the recent study of the

54 Modern.

55 Lipovetsky Poetics.

56 The first to (erroneously) predict that the possession of nuclear technologies would hasten the transformation of democracies into dictatorships was JUNGK Atomstaat. Recently, the concept of authoritarian modernisation has suggested a more nuanced interpretation of the connections between authoritarianism and specific patterns of techno-scientific development. See, e. g. GEL'MAN (ed.): Modernization.

The term "nuclear priesthood" can be traced back to LIFTON/FALK Indefensible Weapons, p. 31.

KRIGE/BARTH Introduction, pp. 5-9.

See e. g. the chapters on nuclear topics in LEFFLER/WESTAD (eds.): Cambridge History of the Cold War. 
post-Stalinist Soviet Union. ${ }^{60}$ Bringing the technical intelligentsia back into the picture of late Soviet history is crucial if we are to gain a realistic understanding of the elites on whose support the post-Stalinist state relied, particularly in view of the fact that the sprawling technical intelligentsia co-defined the late Soviet project to a significant extent and therefore had a manifest interest in its continued existence.

Third, a multi-level approach can complement the prevailing genre of national nuclear histories in illuminating ways. This is by no means to say that the question of how the atom inspired high-modern projects of nation-building - or the "construction of Communism" - have become unproductive, let alone irrelevant. However, a more deliberate inclusion of local and global perspectives offers a wealth of new insights waiting to be tapped into. Thus, the close study of nuclear research and production centres reveals the micro-logic of how loyalty and dissent, knowledge and ignorance, privilege and deprivation were traded and negotiated. ${ }^{61}$ More studies are needed to further explore these dynamics. Conversely, a focus on international cooperation highlights the interconnectedness of Soviet and global nuclear histories and draws attention to techno-diplomacy as an alternative channel of superpower relations in which opposing geopolitical worldviews were mitigated by shared technocratic mindsets. Clearly, Soviet nuclear history was written not only in Moscow, but also in Cheliabinsk, Obninsk, Shevchenko, Geneva and Vienna.

When scholars first started to explore Soviet nuclear history in depth a quarter of a century ago, it seemed as if the subject could be consigned to the past fairly expediently and with a rather specific historical meaning. In the aftermath of the Chernobyl catastrophe, it appeared to epitomise the specific inferiority of Soviet science, technology, economy and politics. Ironically, from today's perspective, it appears considerably more ambiguous and open-ended as a result of both domestic and international developments. In view of the nuclear accident at Fukushima in 2011, Chernobyl has lost its singular historical status and has belatedly been acknowledged as offering important comparative lessons for the interpretation of the gains and losses of global high modernity in general. Equally significant, the nuclear industry, once seen as the late USSR's greatest liability and a heavy burden on its post-Soviet successor states, has recently emerged like a phoenix from the ashes and is today considered a major technological and economic asset by Russia's political leadership. While scepticism about the future prospects of the industry may well be warranted, it cannot be ignored that even after Fukushima, a nuclear renaissance unfolds with unabated momentum in some parts of the world. Clearly, against the background of these developments, the nuclear age cannot be consigned to history just yet, and the study of its past still holds significant explanatory potential for the present and future of a techno-scientific modernity which, despite numerous claims to the contrary, continues to escape obsolescence.

60 Most prominently YURCHAK Everything.

61 See the contributions by Khandozhko, Sembritzki, Guth. 


\section{Literature}

ARndt, Melanie (ed.): Politik und Gesellschaft nach Tschernobyl. (Ost-)Europäische Perspektiven. Berlin 2016.

BALOČKAité, RASA Post-Soviet Transitions of the Planned Socialist Towns: Visaginas, Lithuania, in: Studies of Transition States and Societies 2 (2010), 2, pp. 63-81.

Brown, Kate Plutopia. Nuclear Families, Atomic Cities and the Great Soviet and American Plutonium Disasters. Oxford 2013.

Callon, michel Acting in an Uncertain World. An Essay on Technical Democracy. Cambridge, Mass. 2009.

COChran, thomas B. / NORris, Robert S. / Bukharin, oleg A. Making the Russian Bomb from Stalin to Yeltsin. Boulder, San Francisco, Oxford 1995.

DALHOUSKI, ALIAKsandR Tschernobyl in Belarus. Ökologische Krise und sozialer Kompromiss (1986-1996). Wiesbaden 2015.

DAvid-Fox, MiCHAEL The Iron Curtain as Semipermeable Membrane: Origins and Demise of the Stalinist Superiority Complex, in: Babiracki, Patryk / Zimmer, Kenyon (eds.): Cold War Crossings. College Station 2014, pp. 14-39.

DAWSON, JANE I. Eco-Nationalism: Anti-Nuclear Activism and National Identity in Russia, Lithuania and Ukraine. Durham 1996.

DOING, PARK Give Me a Laboratory and I Will Raise a Discipline: The Past, Present, and Future Politics of Laboratory Studies in STS, in: Hackett, Edward J. / Amsterdamska, Olga / Lynch, Michael / Wajcman, Judy (eds.): The Handbook of Science and Technology Studies. Cambridge, MA 2008, pp. 279-295.

emeliantseva, ekaterina The Privilege of Seclusion: Consumption Strategies in the Closed City of Severodvinsk, in: Ab Imperio (2011), 2, pp. 238-259.

eVAngelista, Matthew Unarmed Forces: The Transnational Movement to End the Cold War, Ithaca, N. Y. 1999.

Fedoseyev, pyotr Social Significance of the Scientific and Technological Revolution, in: Dahrendorf, Ralf (ed.): Scientific-Technological Revolution. Social Aspects. London, Beverly Hills 1977, pp. 83-107.

FÜRST, JULIANE / JONES, POLLY / MORRISSEY, SUSAN (eds.): The Relaunch of the Soviet Project, 1945-64. = Slavonic and East European Review, 86 (2008), 2.

GeIST, EDWARD Political Fallout: The Failure of Emergency Management at Chernobyl', in: Slavic Review 74 (2015), 1, pp. 104-126.

GeL'MAN, Vladimir (ed.): Authoritarian Modernization in Russia. Ideas, Institutions, and Policies. London, New York 2017.

GeSTWA, KLAUS / ROHDEWALD, STefan Verflechtungsstudien. Naturwissenschaft und Technik im Kalten Krieg, in: Osteuropa 59 (2009), 10, pp. 5-14.

GeSTWA, KlaUs Die Stalinschen Großbauten des Kommunismus. Sowjetische Technik- und Umweltgeschichte, 1948-1967. München 2010.

GESTWA, KLAUS Katastrojka und Super-GAU. Die Nuklearmoderne in Zeiten von Tschernobyl und Fukushima, in: Kucher, Katharina / Thum, Gregor / Urbansky, Sören (eds.): Stille Revolutionen. Die Neuformierung der Welt seit 1989. Frankfurt a. M. 2013, pp. 57-72.

GHEORGHE, ELIZA Building Détente in Europe? East-West Trade and the Beginnings of Romania's Nuclear Programme, 1964-70, in: European Review of History 21 (2014), 2, pp. $235-253$.

Gordin, MiChAel D. Red Cloud at Dawn: Truman, Stalin, and the End of the Atomic Monopoly. New York 2009.

gubarev, Vladimir s. Atomnye goroda. Moskva 1968.

Guth, Stefan One Future Only? The Soviet Union in the Age of the Scientific-Technical Revolution, in: Journal of Modern European History 13 (2015), 3, pp. 355-376. 
HeCht, Gabrielle / EDWARDS, PAUl N. The Technopolitics of Cold War. Toward a Transregional Perspective, in: Adas, Michael (ed.): Essays on Twentieth Century History. Philadelphia 2010, pp. 271-314.

HeCHT, GABRIELLE Being Nuclear. Africans and the Global Uranium Trade. Cambridge, MA 2012. HECHT, GABRIELle The Radiance of France: Nuclear Power and National Identity after World War II. 2nd ed. Cambridge, MA 2009.

HoffMANn, ERIK P. / LAIRD, ROBbin F. Technocratic Socialism: The Soviet Union in the Advanced Industrial Era. Durham 1985.

hoffmann, ERIK P. / LAIRD, ROBbin F. The "Scientific-Technological Revolution" and Soviet Foreign Policy. New York 1982.

Holloway, David Stalin and the Bomb. The Soviet Union and Atomic Energy 1939-1956. New Haven, London 1994.

Holloway, DAvid The Soviet Union and the Creation of the International Atomic Energy Agency, in: Cold War History 16 (2016), 2, pp. 177-194.

ichikawa, Hiroshi Obninsk, 1955. The World's First Nuclear Power Plant and "The Atomic Diplomacy" by Soviet Scientists, in: Historia Scientiarum 26 (2016), pp. 25-41.

JASANOFF, SheIla / KIM, SANG-HYUN Containing the Atom: Sociotechnical Imaginaries and Nuclear Power in the United States and South Korea, in: Minerva 47 (2009), 2, pp. 119-146.

JASANOFF, SHeILA Future Imperfect: Science, Technology, and the Imaginations of Modernity, in: Jasanoff, Sheila / Kim, Sang-Hyun (eds.): Dreamscapes of Modernity. Sociotechnical Imaginaries and the Fabrication of Power. Chicago, London 2015, pp. 1-33.

JASANOFF, SheILA Imagined and Invented Worlds, in: Jasanoff, Sheila / Kim, Sang-Hyun (eds.):

Dreamscapes of Modernity. Sociotechnical Imaginaries and the Fabrication of Power. Chicago, London 2015, pp. 321-341.

JASAnoff, Sheila The Idiom of Co-Production, in: Jasanoff, Sheila (ed.): States of Knowledge.

The Co-Production of Science and Social Order. London, New York 2004, pp. 1-12.

Josephson, PAUl R. Atomic-Powered Communism. Nuclear Culture in the Postwar USSR, in: Slavic Review 55 (1996), 2, pp. 297-324.

Josephson, PAUl R. Red Atom. Russia's Nuclear Power Program from Stalin to Today. New York 2000.

JUngK, Robert Der Atom-Staat. Vom Fortschritt zur Unmenschlichkeit. München 1977.

KALMbACH, Karena Revisiting the Nuclear Age. State of the Art Research in Nuclear History, in:

Neue Politische Literatur 62 (2017), 1, pp. 49-70.

KOHLRAUSCH, MARTIN / STEFFEN, KATRIN / WIEDERKEHR, STEFAN (eds.): Expert Cultures in

Central Eastern Europe: The Internationalization of Knowledge and the Transformation of Na-

tion States Since World War I. Osnabrück 2010.

KOHLRAUSCH, MARTIN / TRISCHLER, HELMUTH Building Europe on Expertise. Innovators, Organizers, Networkers. Basingstoke 2014.

kuchinskaya, olga The Politics of Invisibility. Public Knowledge about Radiation Health Effects after Chernobyl. Cambridge, MA 2014.

LATOUR, BRUno Reassembling the Social. Oxford 2007.

LATOUR, BRUno We Have Never Been Modern. New York 1993.

LEFFleR, MELvyn P. / WeStAd, OdD ARne (eds.): The Cambridge History of the Cold War. 3 vols. Cambridge 2010 .

LIBURKINA, RUZANA / NIEWÖHNER, JÖRG Einführung [to the chapter Laborstudien], in: Bauer, Susanne / Heinemann, Torsten/Lemke, Thomas (eds.): Science and Technology Studies. Klassische Positionen und aktuelle Perspektiven. Berlin 2017, pp. 173-197.

lifton, robert J./Falk, Richard a. Indefensible Weapons. The Political and Psychological Case against Nuclearism. New York 1982. 
Lipovetsky, mark The Poetics of ITR Discourse: in the 1960s and Today, in: Ab Imperio 14 (2013), 1, pp. 109-131.

LOCK, WILliam O. A History of the Collaboration Between the European Organization for Nuclear Research (CERN) and the Joint Institute for Nuclear Research (JINR), and with Soviet Research Institutes in the USSR, 1955-1970, June, 1975, http://cds.cern.ch/record/186009 (31.10.2017).

Man, Science, Technology: A Marxist Analysis of the Scientific and Technological Revolution. Moscow, Prague 1973. [Originally in Russian: Chelovek - nauka - tekhnika. Moskva 1973].

Medvedev, zhores A. Nuclear Disaster in the Urals. New York 1980.

melnikova, NAtAlia Les artisans du projet nucléaire, in: Kondratieva, Tamara (ed.): Les Soviétiques, un pouvoir, des régimes. Paris 2011, pp. 51-73.

PÉTERI, GYÖRGY Nylon Curtain. Transnational and Transsystemic Tendencies in the Cultural Life of State-Socialist Russia and East-Central Europe, in: Slavonica 10 (2004), 2, pp. 113-123.

petros'iants, A. M. / Shegel'skiI, A. v. / KrUglov, A. K. [et al.] (eds.): Iadernaia industriia Rossii. Moskva 2000.

PETRYNA, ADRIANa Life Exposed: Biological Citizens after Chernobyl. Princeton 2002.

Plaggenborg, Stefan Sowjetische Geschichte in der Zeitgeschichte Europas, Version: 1.o, in: Docupedia-Zeitgeschichte (30.09.2011), http://docupedia.de/zg/Sowjetische_Geschichte (15.12.2017).

PRITCHARD, SARA B. An Envirotechnical Disaster: Nature, Technology, and Politics at Fukushima, in: Environmental History 17 (2012), 2, pp. 219-243.

PRITCHARD, SARA B. Confluence: The Nature of Technology and the Remaking of the Rhone. Cambridge, MA 2011.

RENNER, ANDREAS Ein Ort, drei Erinnerungen. Hiroshima aus sowjetischer Sicht, in: Osteuropa 63 (2013), 7, pp. 139-168.

RHODES, Richard Dark Sun: The Making of the Hydrogen Bomb. New York 1995.

RHODES, RICHARD The Making of the Atomic Bomb. New York 1986.

RIABEV, LEV D. (ed.): Atomnyi Proekt SSSR. 3 vols. Moskva 1998-2009.

roehrlich, Elisabeth The Cold War, the Developing World, and the Creation of the International Atomic Energy Agency (IAEA), 1953-1957, in: Cold War History 16 (2016), 2, pp. 195-212.

SChmid, sonja D. Celebrating Tomorrow Today. The Peaceful Atom on Display in the Soviet Union, in: Social Studies of Science 36 (2006), 3, pp. 331-365.

SCHmid, sonjA D. Nuclear Colonization? Soviet Technopolitics in the Second World, in: Hecht, Gabrielle (ed.): Entangled Geographies: Empire and Technopolitics in the Global Cold War. Cambridge, MA 2011, pp. 125-154.

SCHMID, SONJA D. Organizational Culture and Professional Identities in the Soviet Nuclear Power Industry, in: Osiris 23 (2008), pp. 82-111.

SCHMID, sonjA D. Producing Power: The Pre-Chernobyl History of the Soviet Nuclear Industry. Cambridge, MA 2015.

SCHMID, SONJA D. Shaping the Soviet Experience of the Atomic Age: Nuclear Topics in Ogonyok, 1945-1965, in: Van Lente, Dick (ed.): The Nuclear Age in Popular Media. A Transnational History, 1945-1965. New York 2012, pp. 19-51.

SID orenko, viktor A. Istoriia atomnoi energetiki Sovetskogo Soiuza i Rossii. 5 vols. Moskva 2001-2004.

ŠLIAVAITĖ, KRISTINA Social Memory, Identity and Narratives of Decline in a Lithuanian Nuclear Plant Community, in: Acta Historica Universitatis Klaipedensis 20: Studia Anthropologica 4 (2010), pp. 52-71.

Stawkowski, Magdalena "I Am a Radioactive Mutant": Emergent Biological Subjectivities at Kazakhstan’s Semipalatinsk Nuclear Test Site, in: American Ethnologist 43 (2016), 1, pp. 144157. 
Storm, ANnA Post-Industrial Landscape Scars. New York 2014.

TEICH, Mikuláš J. D. Bernal the Historian and the Scientific-Technical Revolution, in: Interdisciplinary Science Reviews 33 (2008), 2, pp. 135-139.

TURCHETTI, SIMONE / HERRAN, NÉSTOR / BOUdiA, SORAYA Introduction: Have We Ever Been

"Transnational"? Towards a History of Science Across and Beyond Borders, in: British Journal for the History of Science 45 (2012), 3, pp. 319-336.

van Lente, Dick (ed.): The Nuclear Age in Popular Media. A Transnational History, 1945-1965.

New York 2012.

VASIlieva, MARIA Soleils rouges: L’ambition nucléaire soviétique. Paris 1999.

viZGIN, v. P. Fenomen “kul'ta atoma” v SSSR (1950-1960e gg.), in: Vizgin, V.P. (ed.): Istoriia sovetskogo atomnogo proekta: dokumenty, vospominaniia, issledovaniia. 2 vols. Vol. 2. Sankt-Peterburg 2002, pp. 413-488.

volkov, GenRikh N. Man and the Scientific and Technological Revolution. Moskva 1975.

Weiner, Douglas R. A Little Corner of Freedom: Russian Nature Protection from Stalin to Gorbachev. Berkeley 1999.

wendland, anna veronika Tschernobyl: (k)eine Visuelle Geschichte. Nukleare Bilderwelten in der Sowjetunion und ihren Nachfolgestaaten 1970-2011, in: Arndt, Melanie (ed.): Politik und Gesellschaft nach Tschernobyl. (Ost)Europäische Perspektiven. Berlin 2016, pp. 182-201.

white, Sarah Siberian Water to Flow to the Caspian?, in: New Scientist and Science Journal (May 20, 1971), pp. 472-473.

WUNDERLE, ULRIKE Experten im Kalten Krieg: Kriegserfahrungen und Friedenskonzeptionen US-amerikanischer Kernphysiker 1920-1963. Paderborn 2015.

YURCHAK, ALEXeI Everything was Forever, Until it was no More: The Last Soviet Generation. Princeton 2006.

STEFAN GUTH, PHD

postdoctoral researcher at the Institute of East European History of the University of Tübingen, Eberhard-Karls-Universität Tübingen, Philosophische Fakultät, Institut für Osteuropäische Geschichte und Landeskunde, Wilhelmstr. 36, D-72074 Tübingen.

(stefan.guth@uni-tuebingen.de).

FABIAN LÜSCHER, M. A.

PHD student and research assistant at the History Department of the University of Bern. Universität Bern, Historisches Institut, Unitobler, Länggassstrasse 49, 3000 Bern 9. (fabian.luescher@hist.unibe.ch).

\section{JULIA RICHERS, PHD}

is professor for Modern General and Eastern European History at the History Department of the University of Bern. Universität Bern, Historisches Institut, Unitobler, Länggassstrasse 49, 3000 Bern 9. (julia.richers@hist.unibe.ch). 